\title{
Stability-indicating RP-HPLC method for determination of beclomethasone dipropionate in nanocapsule suspensions
}

\author{
Janaíne Micheli Chassot ${ }^{1}$, Luana Mota Ferreira1 ${ }^{1}$, Felipe Pereira Gomes ${ }^{1}$, Letícia Cruz ${ }^{1}$, \\ Leandro Tasso ${ }^{2, *}$
}

\author{
${ }^{1}$ Department of Industrial Pharmacy, Federal University of Santa Maria, Santa Maria, RS, Brazil, ${ }^{2}$ University of Caxias do \\ Sul, Caxias do Sul, RS, Brazil
}

\begin{abstract}
A simple stability-indicating RP-HPLC/UV method was validated for determination of beclomethasone dipropionate (BD) in nanocapsule suspensions. Chromatographic conditions consisted of a $\mathrm{RP} \mathrm{C}_{18}$ column (250 mm x $4.60 \mathrm{~mm}, 5 \mu \mathrm{m}, 110 \AA)$ ), using methanol and water $(85: 15 \mathrm{v} / \mathrm{v})$ as mobile phase at $1.0 \mathrm{~mL} /$ min with UV detection at $254 \mathrm{~nm}$. The calibration curve was found to be linear in the concentration range of 5.0-25.0 $\mu \mathrm{g} / \mathrm{mL}$ with a correlation coefficient $>0.999$. Precision was demonstrated by a relative standard deviation lower than $2.0 \%$. Accuracy was assessed by the recovery test of BD from nanocapsules $(98.03 \%$ to $100.35 \%)$. Specificity showed no interference from the components of nanocapsules or from the degradation products derived from acid, basic and photolytic conditions. In conclusion, the method is suitable to be applied to assay BD in bulk drug and in nanocapsules, and it can be employed to study stability and degradation kinetics.
\end{abstract}

Uniterms: High performance liquid chromatography/reverse phase/quantitative analysis. Beclomethasone dipropionate/determination. Nanocapsule/suspensions. Nanoparticles.

\begin{abstract}
Um método simples de CLAE-FR/UV indicativo de estabilidade foi validado para a determinação do dipropionato de beclometasona (BD) em suspensões de nanocápsulas. As condições cromatográficas foram: coluna C18 fase reversa ( $250 \mathrm{~mm}$ x 4,60 mm, $5 \mu \mathrm{m}, 110 \AA$ ), usando como fase móvel metanol e água $(85: 15 \mathrm{v} / \mathrm{v})$ a $1,0 \mathrm{~mL} / \mathrm{min}$, com detecção UV a $254 \mathrm{~nm}$. A curva de calibração foi linear no intervalo de 5,0-25,0 $\mu \mathrm{g} / \mathrm{mL}$ com coeficiente de correlação $>0,999$. A precisão foi demonstrada por um desvio padrão relativo menor que $2,0 \%$. A exatidão foi avaliada pelo teste de recuperação do BD a partir das nanocápsulas $(98,03 \%$ a 100,35\%). O teste de especificidade não mostrou interferência dos componentes das nanocápsulas e nem dos produtos de degradação derivados de condições ácidas, básicas e fotolíticas. Em conclusão, o método é adequado para ser aplicado na avaliação do BD puro e em nanocápsulas e pode ser empregado para o estudo de estabilidade e degradação cinética.
\end{abstract}

Unitermos: Cromatografia líquida de alta eficiência/fase reversa/análise quantitativa. Dipropionato de beclometasona/determinação. Nanocápsulas/suspensões. Nanopartículas.

\section{INTRODUCTION}

Beclomethasone dipropionate $\left(\mathrm{BD} ; \mathrm{C}_{38} \mathrm{H}_{28} \mathrm{ClO}_{7}\right.$; MW: 521.0 Da) (Figure 1), a synthetic chlorinated glucocorticoid diester, is a well-established antiinflammatory agent used in the treatment of asthma (Vidgren et al., 1995). BD is characterized by a white or

\footnotetext{
*Correspondence: L. Tasso. Universidade de Caxias do Sul. Avenida Francisco Getúlio Vargas 1130 - Bairro Petrópolis, 95070-560 - Caxias do Sul, RS, Brazil. E-mail: 1tasso@ucs.br
}

almost white crystalline powder, presenting $\mathrm{pKa}$ of 13.6 and melting range between $117-120^{\circ} \mathrm{C}$ (Wilcox, Avery, 1973; Brogden et al., 1984; Barnes, 2010; ECP, 2010). The mechanism of action of BD occurs at cellular nucleus level by interacting with DNA and hence stimulating or suppressing gene transcription. This drug can act as a transcription factor, altering the expression of target genes in response to a specific hormonal signal (De Kloet et al., 1993).

$\mathrm{BD}$ has been proven to be effective when used by inhalation in asthmatic patients compared to placebo. 


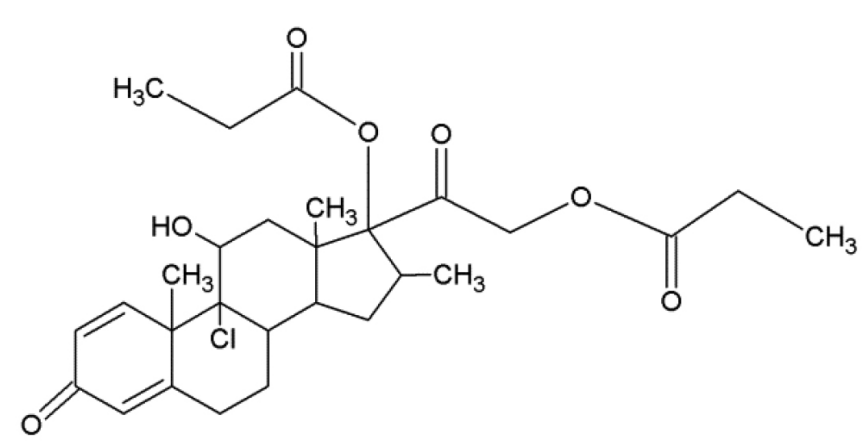

FIGURE 1 - Chemical structure of beclomethasone dipropionate.

In this way, the therapeutic effect of conventional doses of inhaled BD is attributed to its direct action on the respiratory tract (Cole et al., 1999). However, BD is a highly hydrophobic drug, and it thus presents slow dissolution rate within airways and rapid mucociliary clearance, resulting on a relative short local duration of action following administration with a consequent reduction in its therapeutic effect (Jacobs, Müller, 2002; Sakagami et al., 2002). Following powder aerosol administration, BD is partially removed from its primary site of action, the lower airways, by mucociliary clearance prior to dissolution and absorption, and eventually, swallowed into the gastrointestinal tract (Hochhaus et al., 1997). Therefore, BD entrapment within biocompatible and biodegradable nanocarriers is a promising approach to improve therapeutic efficacy, reduce the risk of side effects by prolonging BD retention time in the lung and achieve controlled or targeted drug delivery (Helle et al., 2008).

Nanocapsules are colloidal drug carriers characterized by a lipophilic core surrounded by a polymeric layer, in which the drug can be dissolved in the oily core and/or adsorbed on the polymeric wall (Schaffazick et al., 2003). The advantages of using such colloidal carriers include: potential to increase the bioavailability of poorly water-soluble drugs, ability to control the rate and/or the site of drug release and possibility to improve drug stability related to enzymatic, immunological or chemical/photochemical degradation, among others (Couvreur, Vauthier, 2006). In this way, experiments are being conducted in our laboratory in order to formulate BD-loaded biodegradable nanocapsules. At the same time, it is necessary to work with a validated analytical technique for assaying $\mathrm{BD}$ in these formulations.

A literature review indicated few HPLC methods to determine $\mathrm{BD}$ in pharmaceutical formulations. BD is officially listed in the British and in the US Pharmacopeias. In the first one, a laborious method was described using elution by gradient, elevated temperature, and presenting retention time of 25 min (British Pharmacopeia, 2010). In its turn, US Pharmacopeia (USP, 2009) reports a simpler HPLC method with a mobile phase constituted by acetonitrile and water elution at room temperature. Retention time is approximately $6 \mathrm{~min}$. In the open literature, validated analytical methods for the analysis of BD in bulk drug and pharmaceutical formulations were not found. In relation to the analysis of BD in biological fluids, Foe and co-workers (Foe et al., 2000) compared the kinetic disposition and metabolism of BD and its monopropionate ester in human lung homogenates and plasma using a HPLC method with an isocratic mobile phase. UV detection was performed at $242 \mathrm{~nm}$. According to Girault and co-workers, low levels of corticosteroids cannot be accurately measured with conventional HPLC methods due to lack of sensitivity. For this reason, HPLC coupled to mass spectrometry has been used for BD quantification in complex biological matrices (Girault et al., 1991; Taylor, Grebe, Sing, 2004).

According to the stability guideline of the International Conference on Harmonization (ICH, 2003), stress testing of a drug substance can be carried out to elucidate its inherent stability characteristics under hydrolytic, oxidative and photolytic conditions.

Taking all of this into account, in the present study, a simple reverse-phase HPLC method with UV detection was validated for quantifying BD in nanocapsules, as well as to study forced degradation of the drug under stress conditions. The experiments were performed in accordance with ICH guideline parameters (ICH, 1996; ICH, 2003; ICH, 2005). It is relevant to mention that the method developed in our work is easy, low cost and employ few raw materials to quantify BD in nanocapsules.

\section{MATERIAL AND METHODS}

\section{Material}

Beclomethasone dipropionate $(97 \% \mathrm{w} / \mathrm{w})$ was obtained from Henrifarma (São Paulo, Brazil). Poly ( $\varepsilon$-caprolactone) (PCL) and Span $80^{\circledR}$ (sorbitan monooleate) were acquired from Sigma Aldrich (São Paulo, Brazil). Tween $80^{\circledR}$ (polysorbate 80 ) was purchased from Delaware (Porto Alegre, Brazil). Sweet almond oil was kindly donated by Campestre (São Bernardo do Campo, Brazil). HPLC-grade methanol was purchased from Tedia (São Paulo, Brazil). Ultrapure water was obtained from a Milli- ${ }^{\circledR}$ Plus apparatus (Millipore, Billerica, USA). All other solvents and reagents were of analytical grade and used as received. 


\section{Apparatus and chromatographic conditions}

All the experiments were performed on a Shimadzu LC-10A HPLC system (Kyoto, Japan) fitted with a LC-10 ADVP pump, an UV-VIS SPD-10AVP detector, a SCL10AVP system controller, and a Rheodyne valve sample manual injector with $50 \mu \mathrm{L}$ loop. For separations, a RP $\mathrm{C}_{18}$ Phenomenex column ( $250 \mathrm{~mm} \times 4.60 \mathrm{~mm}, 5 \mu \mathrm{m}$ particle size, $110 \AA$ pore diameter) was used at room temperature as well as a mobile phase consisting of methanol and water $(85: 15 \mathrm{v} / \mathrm{v})$ at isocratic flow rate $(1.0 \mathrm{~mL} / \mathrm{min})$. The injection volume was $50 \mu \mathrm{L}$ and the detection was monitored at a wavelength of $254 \mathrm{~nm}$. The peak areas were automatically integrated by the Class VP solution software program. In order to protect the analytical column, a guard column was used (Security Guard $\mathrm{C}_{18} 4$ x $3.0 \mathrm{~mm}$ ).

\section{Preparation of nanocapsule suspensions}

BD-loaded nanocapsule suspensions were prepared by interfacial deposition of preformed polymers (Fessi, Puisieux, Devissaguet, 1988). An organic solution consisting of acetone, $\mathrm{BD}(0.5 \mathrm{mg} / \mathrm{mL})$, PCL $(1 \mathrm{mg} / \mathrm{mL})$, sorbitan monooleate $(0.77 \mathrm{mg} / \mathrm{mL})$ and almond oil $(3$ $\%)$ was added into an aqueous solution of polysorbate $80(0.77 \mathrm{mg} / \mathrm{mL})$ under moderate magnetic stirring at $40{ }^{\circ} \mathrm{C}$. After $10 \mathrm{~min}$, the acetone was eliminated and the water was concentrated under reduced pressure to achieve $0.5 \mathrm{mg} / \mathrm{mL}$ of BD. The sample was named NC-BD. For comparison purposes, a blank formulation was prepared while omitting the drug (NC-B).

\section{Preparation of standard and sample solutions}

A stock standard solution $(0.5 \mathrm{mg} / \mathrm{mL})$ of BD was prepared by accurately weighing $0.0125 \mathrm{~g}$ of drug, transferring to $25 \mathrm{~mL}$ volumetric flask and making up to volume with methanol. For BD quantification in the nanocapsules and evaluation of the validation parameters, the suspensions were diluted with methanol, sonicated for $10 \mathrm{~min}$ and then subjected to centrifugation for $20 \mathrm{~min}$ to extract the drug. All solutions were filtered through a regenerated cellulose membrane (pore size $0.45 \mu \mathrm{m}$ ) before HPLC injection $(n=3)$.

\section{Method development}

Detection wavelength for the HPLC study was selected at $254 \mathrm{~nm}$. The chromatographic conditions were optimized for resolution of the peak of BD and degradation products under each forced degradation condition by varying the proportion of methanol-water in the mobile phase. Samples of different stress conditions were used to optimize the chromatographic conditions for resolving BD and all the degradation products in a single run. An appropriate blank was injected before the analysis of all forced degradation samples. The method was then validated and applied for the determination of $\mathrm{BD}$ in nanocapsule suspensions.

\section{Method validation}

Validation studies were conducted using the optimized assay conditions based on the principles of validation described in the ICH guidelines (ICH, 2005). The method was validated for specificity, linearity, limit of detection (LOD), limit of quantitation (LOQ), accuracy, precision, and robustness.

Specificity was determined by analyzing the chromatograms of unloaded nanocapsule suspensions (blank nanocapsules) in comparison with those obtained for BD-loaded nanocapsules, in order to confirm that none of the excipients interfere with the quantitation of the drug. Peaks due to degraded products and excipients were examined.

Linearity test solutions for the assay method were prepared from BD stock solutions at five concentration levels $(5.0,10.0,15.0,20.0$, and $25.0 \mu \mathrm{g} / \mathrm{mL})$. The peak area versus concentration data was performed by leastsquares linear regression analysis. The calibration graph was obtained by plotting the peak areas of the standard solutions against standard concentrations. The linearity test was performed for 3 consecutive days in the same concentration range for the assay method. The solutions were injected in triplicate into the HPLC column keeping the injection volume constant $(50 \mu \mathrm{L})$, and chromatograms were recorded. The relative standard deviation (RSD \%) value for the slope and $Y$-intercept of the calibration curve were calculated.

LOD and LOQ were calculated based on the standard deviation of the response $(\delta)$ and the slope (S) of the calibration curve and were expressed as $3.3 \delta / \mathrm{S}$ and $10 \delta / \mathrm{S}$, for LOD and LOQ, respectively.

The accuracy of the analytical method was investigated by spiking blank nanocapsules with known concentrations of the stock solution to achieve final theoretical drug concentrations of 7.5, 12.5 and $17.5 \mu \mathrm{g} /$ $\mathrm{mL}$. The analyses were performed in triplicate on three different days.

The precision of the assay method was determined in two levels: repeatability (intraday precision) and intermediate precision (interday precision). Six samples 
of nanocapsules $(15 \mu \mathrm{g} / \mathrm{mL})$ were assessed on the same day in order to evaluate the repeatability of the method and on two different days in order to determine intermediate precision. Results were reported in terms of relative standard deviation (RSD \%).

To determine the robustness of the method, experimental conditions were purposely altered to check the reproducibility of the method. Robustness was evaluated by analyzing drug content of the nanocapsules with small variations in flow rate $(0.9$ and $1.1 \mathrm{~mL} /$ min) and composition of the mobile phase (80:20 and 90:10 methanol/water, v/v). Samples were evaluated in triplicate for each variation of the method conditions. Chromatograms were recorded and compared with the chromatographic conditions mentioned earlier.

Forced degradation studies were also carried out in order to provide some information about drug stability and specificity of the proposed method. The standard solution of BD was subject to accelerated degradation by acid, basic and photolytic conditions. To study the acid degradation, $6.25 \mathrm{~mL}$ of the stock solution $(1.0 \mathrm{mg} /$ $\mathrm{mL}$ of BD) was diluted in a $25 \mathrm{~mL}$ volumetric flask with $0.1 \mathrm{~mol} / \mathrm{L} \mathrm{HCl}$. This solution was maintained at room temperature and protected from light for $1 \mathrm{~h}$. After the reaction time, the solution was neutralized with $0.1 \mathrm{~mol} / \mathrm{L}$ $\mathrm{NaOH}$. The solution was diluted with methanol to achieve a final concentration of $15 \mu \mathrm{g} / \mathrm{mL}$ before injection into the HPLC system. The same procedure was adopted for the alkaline degradation, except by the fact that $0.1 \mathrm{~mol} / \mathrm{L} \mathrm{HCl}$ was replaced by $0.1 \mathrm{~mol} / \mathrm{LNaOH}$ in sample preparation. For photodegradation, $1.5 \mathrm{~mL}$ of BD methanolic solution $(0.5 \mathrm{mg} / \mathrm{mL}$ of BD; BD-MS) was placed in a plastic cuvette and subsequently exposed to UV radiation (Phillips TUV lamp-254 nm, $30 \mathrm{~W}$ ) for $6 \mathrm{~h}$ in a mirrored chamber ( $1 \mathrm{~m} \mathrm{x}$ $25 \mathrm{~cm} \times 25 \mathrm{~cm}$ ), at a fixed distance. At predetermined times $(0,1,2,3,4$ and $5 \mathrm{~h})$ of exposure to light, $300 \mu \mathrm{L}$ of the samples were withdrawn and diluted with methanol (final concentration of $15 \mu \mathrm{g} / \mathrm{mL}$ of BD) in order to quantify the remaining BD according to the method previously described. In order to refute the hypothesis of thermal degradation, a cuvette containing BD-MS was covered by aluminum paper and was evaluated in the same way. The degradation rate kinetics of BD was determined and the best fit observed indicates the reaction order. The kinetic equations used were: zero order $\left(C=C_{0}-k t\right)$, first order $\left(\ln C=\ln C_{0}-k t\right)$ and second order equation $\left(1 / C=1 / C_{0}+k t\right)$.

\section{Evaluation of encapsulation efficiency}

Encapsulation efficiency was estimated by the ultrafiltration-centrifugation technique using
Amicon Ultra ${ }^{\circledR} 10,000 \mathrm{MW}$ devices (Millipore). After centrifugation at $2200 \mathrm{x}$ g for $10 \mathrm{~min}$, free BD was assayed in the ultrafiltrate. The encapsulation efficiency was calculated as the difference between the total and the free drug concentrations, as follows:

\section{RESULTS AND DISCUSSION}

\section{Optimization of chromatographic conditions}

Viewing to establish the chromatographic conditions, preliminary tests were carried out in order to select the detection wavelength and the mobile phase composition. The organic solvent chosen to compose the mobile phase was methanol because it is more cost-effective than acetonitrile and it is the solvent used to prepare the standard and sample solutions. Initial trials were conducted with mixtures of methanol and ultrapure water in the following proportions: 70:30, 85:15 and 80:20 v/v. The mobile phases were tested at flow rates of $0.8,1.0$ and $1.2 \mathrm{~mL} / \mathrm{min}$. With the aid of a photodiode array detector, the wavelength selected was $254 \mathrm{~nm}$, which is in accordance with USP and British Pharmacopoeias. Considering retention time, peak symmetry, peak selectivity and peak width, the mobile phase of methanol and water $(85: 15, \mathrm{v} / \mathrm{v})$ at $1.0 \mathrm{~mL} / \mathrm{min}$ was considered satisfactory (theoretical plates $=5829$ and tail factor $=1.1)$. Retention time was 5.9 min (Figure $2 \mathrm{a}$ ).

\section{Method validation}

Specificity was evaluated for the influence of the formulation components, as well as for the interference of possible degradation products in the assay of BD. By comparing the both chromatograms presented in Figure 2 , it is possible to conclude that there is no interference from the components of nanocapsules in the drug peak. Moreover, the photodiode array detector showed that the BD peak was free from interferents (purity index $>$ 0.9999).

As for the linearity of the method, there was a linear relationship between peak area and concentration of BD in the concentration range of 5.0-25.0 $\mu \mathrm{g} / \mathrm{mL}$. The linear equation obtained by the least-square method was $\mathrm{y}=56798 \mathrm{x}+6295.1$ and showed an adequate correlation coefficient $(r=0.9993)$. The validity of the assay was verified by analysis of variance (ANOVA), which confirmed that the regression equation was linear $\left(\mathrm{F}_{\text {calculated }}=1793.3864>\mathrm{F}_{\text {critical }}=4.96 ; \mathrm{p}<0.05\right)$ with no linearity deviation $\left(\mathrm{F}_{\text {calculated }}=0.7657<\mathrm{F}_{\text {critical }}=3.71\right.$; $\mathrm{p}<0.05)$. 


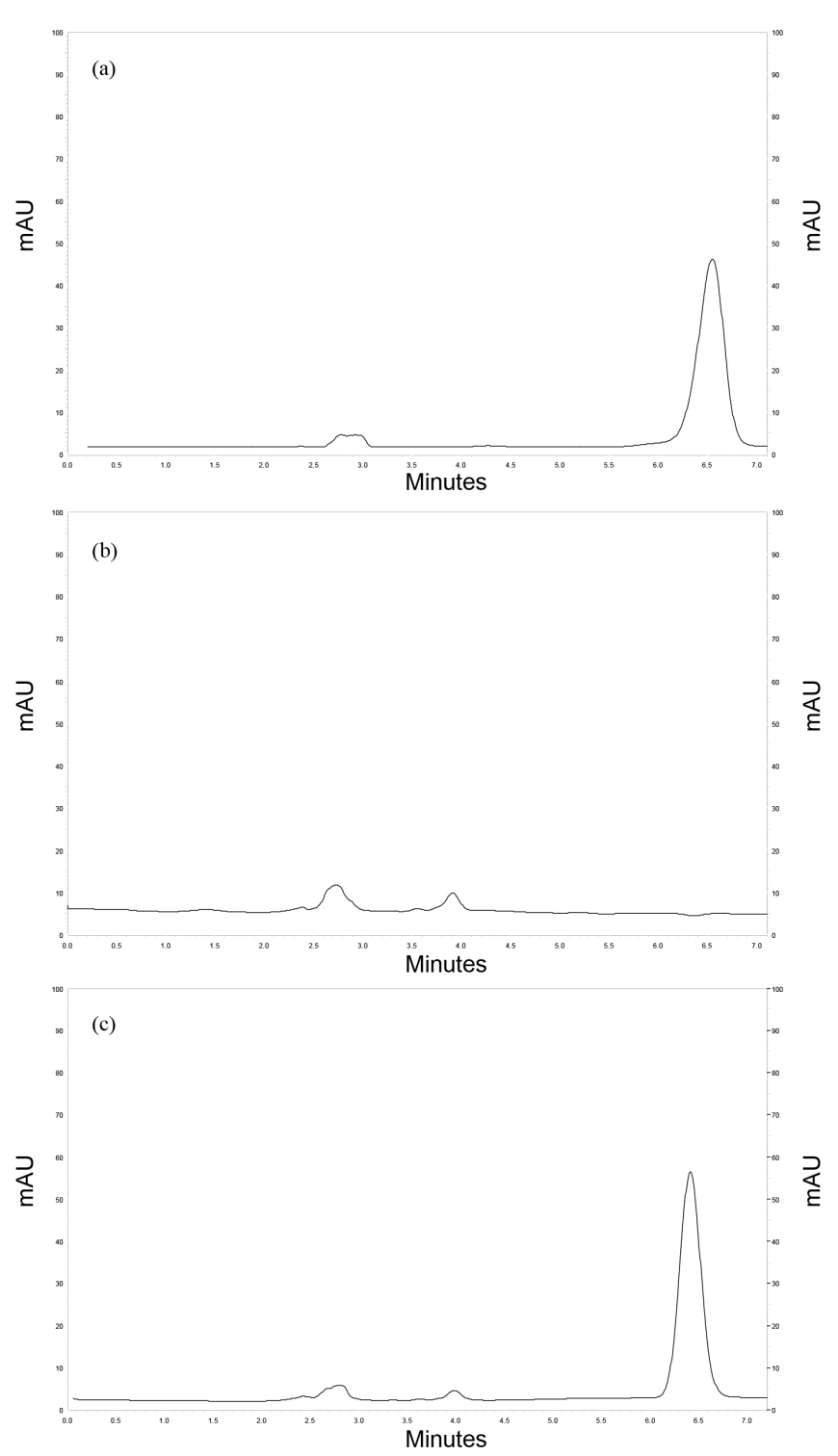

FIGURE 2 - Chromatograms of standard solution (a), blank nanocapsules (b), beclomethasone dipropionate-loaded nanocapsules (c).
The accuracy of the method, evaluated by a recovery study, presented average recoveries for the three levels of concentration ranging from $98 \%$ to $101 \%$ (Table I). Regarding precision, the results of repeatability and intermediate precision showed RSD values lower than $2 \%$. Thus, the proposed analytical method was considered accurate and precise.

Regarding LOD and LOQ, the lowest concentrations assayed with acceptable precision and accuracy were $0.16 \mu \mathrm{g} / \mathrm{mL}$ and $0.54 \mu \mathrm{g} / \mathrm{mL}$, respectively, meaning that the method is sensitive enough to detect and quantitate BD in the concentration range of $5.0-25.0 \mu \mathrm{g} / \mathrm{mL}$.

Concerning the evaluation of robustness, the results showed RSD values lower than $2 \%$, which indicates that changes in the proportion of the mobile phase, as well as variations in the flow rate, did not affect the assay of BD in the nanocapsule suspensions (Table II). Minor variations in the retention time were observed, as expected, without compromising the evaluation of drug concentration.

In relation to the presence of degradation products, forced degradation studies showed different results depending on the stress conditions employed. In alkaline medium, there was significant degradation of BD, (approximately 99\%), with one major additional peak detected at $3.6 \mathrm{~min}$ (Figure 3a). On the other hand, after exposure to $0.1 \mathrm{~mol} / \mathrm{L} \mathrm{HCl}$, approximately $55 \%$ of $\mathrm{BD}$ was degraded (Figure 3b). Chen and co-workers reported the formation of an enol aldehyde from BD and other corticosteroids under acid conditions (Chen et al., 2009). However, the reaction conditions were not the same employed in our study. In that work, the enol aldehyde was generated from concentrated sulfuric acid, which was responsible for the $\beta$-elimination of water from the side chain of corticosteroid (Mattox rearrangement), and under alkaline conditions $(1.0 \mathrm{~N} \mathrm{NaOH})$, there was no degradation of BD.

TABLE I - Accuracy, repeatability and intermediate precision data for beclomethasone dipropionate analysis $(n=3)$

\begin{tabular}{lcccc}
\hline & $\begin{array}{c}\text { Theoretical concentration } \\
(\mu \mathrm{g} / \mathrm{mL})\end{array}$ & $\begin{array}{c}\text { Actual concentration } \\
(\mu \mathrm{g} / \mathrm{mL}) \pm \mathrm{SD}^{*}\end{array}$ & Recovery $(\%)$ & RSD $^{* *}(\%)$ \\
\hline \multicolumn{5}{c}{ Accuracy } \\
\hline Low & 7.5 & $7.41 \pm 0.19$ & 98.73 & 2.61 \\
Medium & 12.6 & $12.22 \pm 0.22$ & 98.03 & 1.36 \\
High & 17.5 & $17.56 \pm 0.10$ & 100.35 & 0.58 \\
\hline \multicolumn{5}{c}{ Repeatability and intermediate precision } \\
\hline Day 1 $(n=6)$ & $15.86 \pm 0.21$ & 99.06 & 1.43 \\
Day 2 $(n=6)$ & 15.00 & $15.27 \pm 0.14$ & 101.85 & 0.96 \\
Mean \pm SD & 15.00 & $15.06 \pm 0.29$ & 99.06 & 1.97 \\
\hline
\end{tabular}

* $\mathrm{SD}=$ Standard Deviation ** $\mathrm{RSD}=$ Relative Standard Deviation. 
TABLE II - Robustness data for beclomethasone dipropionate analysis $(n=3)$

\begin{tabular}{|c|c|c|c|}
\hline & Drug content $(\%)$ & $\mathrm{RSD}^{*}(\%)$ & Retention time (min) \\
\hline \multicolumn{4}{|l|}{ Optimum conditions } \\
\hline 85:15 MeOH:Water; $1.00 \mathrm{~mL} / \mathrm{min}$ & 99.78 & 0.76 & 5.9 \\
\hline \multicolumn{4}{|l|}{ Mobile phase } \\
\hline 90:10MeOH:Water & 100.69 & 0.78 & 4.2 \\
\hline 80:20MeOH:Water & 99.78 & 0.28 & 5.4 \\
\hline \multicolumn{4}{|l|}{ Flow rate } \\
\hline $0.90 \mathrm{~mL} / \mathrm{min}$ & 100.27 & 1.97 & 5.1 \\
\hline $1.10 \mathrm{~mL} / \mathrm{min}$ & 100.28 & 0.73 & 6.3 \\
\hline
\end{tabular}

*RSD= Relative Standard Deviation.
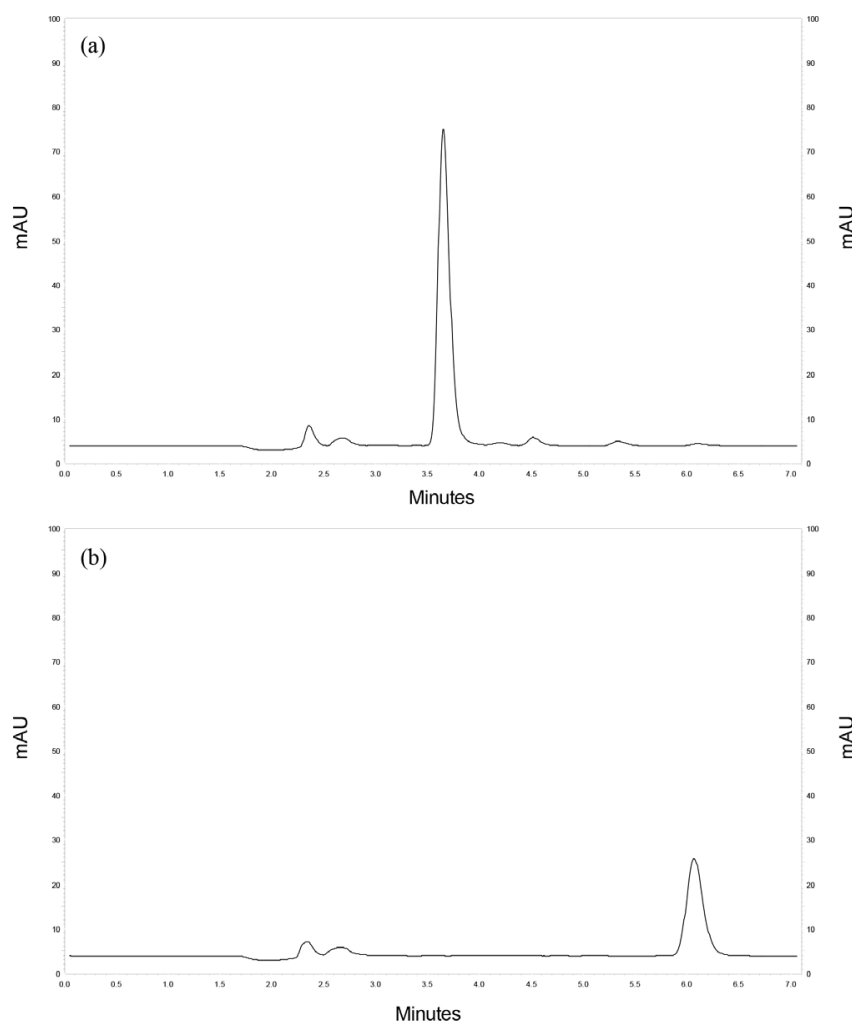

FIGURE 3 - Chromatograms obtained after one hour of BD exposure under alkaline conditions $0.1 \mathrm{~mol} / \mathrm{L} \mathrm{NaOH}$ (a) and under acid conditions $0.1 \mathrm{~mol} / \mathrm{L} \mathrm{HCl}(\mathrm{b})$.

Under photolytic conditions, there were decreases in the BD concentration of the methanolic solution (Figure 4a). No additional peaks appeared in the chromatograms, indicating that the degradation products were not detected under the developed experimental conditions.

Aiming at elucidating the kinetics of photodegradation of BD from solution, the experimental data were fitted to zero, first and second order equations. The plots showed in Figure 4 indicated that the photodegradation process of BD in methanolic solution followed a zero order kinetic with
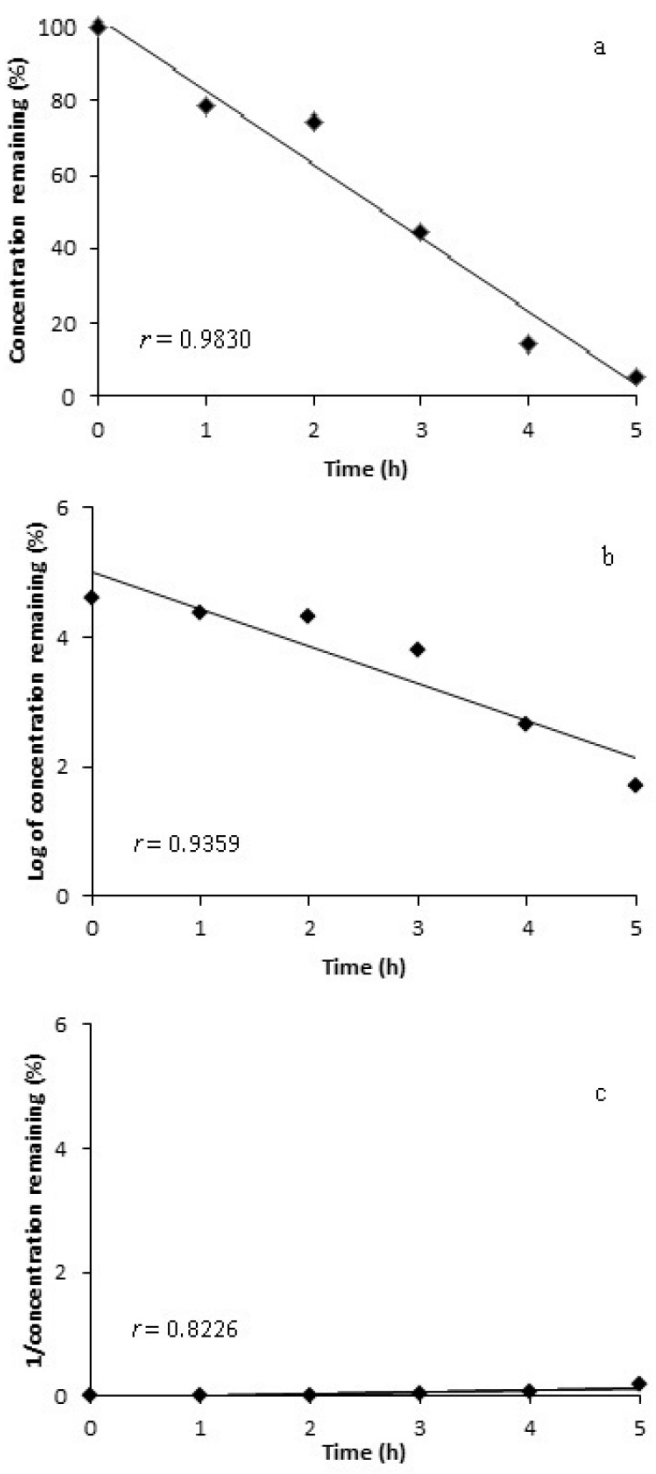

FIGURE 4 - Plots of concentration (a)-zero-order reaction, $\log$ of concentration (b)-first-order reaction, and reciprocal of concentration (c)-second-order reaction of $\mathrm{BD}$ remaining versus time. 
a rate constant of $18.072 \mathrm{~h}^{-1}$. In this case, the degradation of $\mathrm{BD}$ does not depend on drug concentration.

\section{Method application}

In order to show the applicability of the validated method, the drug content and the encapsulation efficiency of BD-loaded nanocapsules were determined. The experimental concentration of the drug in the formulation was according to its theoretical concentration $(0.5 \mathrm{mg} / \mathrm{mL})$ with a low RSD value from the triplicate analysis $(0.51 \pm 0.01 \%)$. As regards the rate of the drug associated with the polymeric nanocapsules, encapsulation efficiency was $99.37 \%$, which can be explained by the lipophilic nature of this drug. Therefore, the validated method was successfully applied to the assay of BD in nanocapsule suspensions and can be considered an important tool in the quality control of these promising formulations.

\section{CONCLUSIONS}

The developed and validated RP-HPLC method proved to be specific, linear, accurate, precise, and robust for the rapid determination of BD in polymeric nanocapsule suspensions, and it can be applied to study the stability and degradation kinetics of the drug.

\section{ACKNOWLEDGMENTS}

Janaíne Micheli Chassot is thankful to CAPES/ Brazil (Coordination for the Improvement of Higher Education Personnel) for the master's fellowship granted.

\section{REFERENCES}

BARNES, P.J. Inhaled glucocorticoids for asthma. N. Engl. J. Med., v.332, p.868-875, 2010.

BROGDEN, R.N., HEEL, R.C., SPEIGHT, T.M., AVERY, G.S. Beclomethasonedipropionate: a reappraisal of its pharmacodynamic properties and therapeutic efficacy after a decade of use in asthma and rhinitis. Drugs, v.28, n.2, p.99-126, 1984.

CHEN, B., LI, M., LIN, M., TUMAMBAC, G., RUSTUM, A. A comparative study of enol aldehyde formation from betamethasone, dexamethasone, beclomethasone and related compounds under acidic and alkaline conditions. Steroids, v.74, n.1, p.30-41, 2009.
COLE, C.H., SHAB, B., ABBASI, S., DEMISSIE, S., MACKINNON, B., COLTON, T., FRAMTZ, I.D. Adrenal function in premature infants during inhaled beclomethasone therapy. J. Pediatr., v.135, n.1, p.65-70, 1999.

COUVREUR, P., VAUTHIER, C. Nanotechnology: intelligent design to treat complex disease. Pharm. Res., v.23, n.7, p.1417-1450, 2006.

DE KLOET, E.R., SUTANTO, W., VAN DEN BERG, D.T., CAREY, M.P., VAN HAARST, A.D., HORNSBY, C.D. Brain mineralocorticoid receptor diversity: functional implications. J. Steroid Biochem. Mol. Biol., v.47, n.1-6, p.183-190, 1993.

EUROPEAN PHARMACOPOEIA COMMISSION. EPC. British Pharmacopoeia. London: HerMajesty, Stationary Office; 1, 2010.

FESSI, H., PUISIEUX, F., DEVISSAGUET, J.P. European Patent 0274961 A1, 1988.

FOE, K., BROWN, K.F., PAUL, J., SEALE, J.P. Comparative kinetics of metabolism of beclomethasone propionate esters in human lung homogenates and plasma. J. Pharm. Sci., v.89, n.9, p.1143-1150, 2000.

GIRAULT, J., ISTIN, B., MALGOUYAT, J.M., BRISSON, A.M., FOURTILLAN, J.B. Simultaneous determination of beclomethasone, beclomethasone monopropionate and beclomethasone dipropionate in biological fluids using a particle beam interface for combining liquid chromatography with negative-ion chemical ionization mass spectrometry. J. Chrom. B: Biomed. Sci. Appl., v.564, n.1, p.43-53, 1991.

HELLE, A., HIRSJÄRVI, L., PELTONEN, L., HIRVONEN, J., WIEDMER, S.K. Quantitative determination of drug encapsulation in poly(lactic acid) nanoparticles by capillary electrophoresis. J. Chromatogr. A., v.1178, n.1-2, p.248$255,2008$.

HOCHHAUS, G., DERENDORF, H., MOELLMAN, H., GONZALEZ-ROTHI, R. Pharmacokinetic/ pharmacodynamic aspects of aerosol therapy using glucocorticoids as a model. J. Clin. Pharmacol., v.37, n.10, p.881-892, 1997. 
INTERNATIONAL CONFERENCE ON HARMONIZATION.

ICH. Photostability testing of new drug substances and products Q1B. Geneva: International Conference on Harmonization (ICH), IFPMA, 1996. 8 p.

INTERNATIONAL CONFERENCE ON HARMONIZATION. ICH. Stability testing of new drug substances and Products Q1A (R2). Geneva: International Conference on Harmonization, IFPMA, 2003. 17 p.

INTERNATIONAL CONFERENCE ON HARMONIZATION. ICH. Validation of ánalytical Procedures: text and methodology Q2 R1. Geneva: International Conference on Harmonization, IFPMA, 2005. 13 p.

JACOBS, C., MÜLLER, R.H. Production and characterization of a budesonide nanosuspension for pulmonary administration. Pharm. Res., v.19, n.2, p.189-194, 2002.

SAKAGAMI, M., KINOSHITA, W., SAKON, K., SATO, J., MAKINO, Y. Mucoadhesive beclomethasone microspheres for powder inhalation: their pharmacokinetics and pharmacodynamics evaluation. J. Control. Release, v.80, n.1-3, p.207-218, 2002.
SCHAFFAZICK, S.R., FREITAS, L.L., POHLMANN, A.R., GUTERRES, S.S. Caracterização e estabilidade físicoquímica de sistemas poliméricos nanoparticulados para administração de fármacos. Quim. Nova, v.26, n.5, p.726737, 2003.

TAYLOR, R.L., GREBE, S.K., SING, R.J. Quantitative, highly sensitive liquid chromatography-tandem mass spectrometry method for detection of synthetic corticosteroids. Clin. Chem., v.50, n.12, p.2345-2352, 2004.

UNITED STATES PHARMACOPEIA. USP. The United States Pharmacopeial Convention. Twinbrook Parkway, Rockville, MD 20852, 2009. 157 p.

WILCOX, J.B., AVERY, G.S. Beclomethasone dipropionate corticosteroid inhaler: a preliminary report of its pharmacological properties and therapeutic efficacy in asthma. Drugs, v.6, n.2, p.84-96, 1973.

VIDGREN, M., WALDREP, J., ARPPE, J., BLACK, M., RODARTE, J., COLE, W., KNIGHT, V. A study of ${ }^{99 \mathrm{~m}}$ technetium-labelled beclomethasone dipropionate dilauroyl phosphatidylcholine liposome aerosol in normal volunteers. Int. J. Pharm., v.115, n.2, p.209-216, 1995.

Received for publication on $02^{\text {nd }}$ March 2015 Accepted for publication on $29^{\text {th }}$ August 2015 